\title{
The Impacts of Non-Performing Loans upon the Prices of Stocks in Jordanian Commercial Banks
}

\author{
Firas Na'el Rawhi Hashem ${ }^{1}$, Khalid Ali Ahmad Alduneibat ${ }^{1} \&$ Mohammad abdallah fayad altawalbeh ${ }^{1}$ \\ ${ }^{1}$ Lecturer, Tafilah Technical University, Jordan \\ Correspondence: Firas Na'el Rawhi Hashem, Lecturer, Tafilah Technical University, Jordan \\ Received: January 19, 2017 \\ Accepted: February 2, 2017 \\ Online Published: February 14, 2017 \\ doi:10.5430/afr.v6n1p139 \\ URL: http://dx.doi.org/10.5430/afr.v6n1p139
}

\begin{abstract}
The purpose of this study can be seen through the major attention that was given to the problem of non-performing loans by the banking institutions. Such attention was given to this problem due to the several impacts it has upon commercial banks and which may extend to affect the whole banking system, the current study aimed at identifying whether there is a statistically significant impact for the non - performing loans upon the prices of stocks or not in Jordanian commercial banks at the significance level of $(a=0.05)$. This study was concerned with investigating the Jordanian commercial banking sector during the period of (2005 -2015). The current study has given great attention to this sector because it is considered as the most vital sector in the Jordanian economic system. This study also shows that there is need for training workers in applying the credit policy that is being adopted. Such training should raise the practical efficiency levels of those employees. The study also showed that banks' control should be stricter and they should set more dissuasive penalties in relation to granting facilities without having adequate guarantees.
\end{abstract}

Keywords: Jordanian Commercial Banks, Prices, Stocks, Loans, Performing

\section{Introduction}

Banks play a major significant role in funding and developing the national economy of the country and its various sectors. That is done through the various functions that they perform. One of the most important functions that they perform is playing the role of the mediator between investors and savors. Credit is considered one of the most significant banking services and activities, because it is considered as something vital for the country's economic activities. In general, bank's efficiency is measured through its ability in employing the money it possesses in the field of credit and other fields in an efficient manner. However, that depends on the quality of the credit. For instance, the more the credit portfolio has quality and less risk, the more positive effects it would have upon the bank's efficiency and profits. Thus, banks usually seek to apply credit policies that are highly efficient in order to assist them in reducing the risk levels that are associated with credit portfolio. Such policies aim to reduce the probabilities of having non-performing loans.

The Jordanian banking sector has been very strict in giving loans due to the raise in the ratio of non-performing loans in Jordanian banks. The amounts of such kind of loans have reached (104.77) million Jordanian Dinar (JDs) in 2015 (cited in www.awraq.com).

The problem of having non-performing loans has been attracting the attention of many researchers, specialists and officials who are working in the banking sector. The spread of this phenomenon in banks can be attributed to a number of economic, social and political factors that govern the financial market. Its spread can be also attributed to some reasons that are related to lenders and borrowers. However, most specialists believe that the raise in the ratio of non-performing loans can be attributed to the decrease in banks' efficiency in managing credit and to the nature of the credit policies that are being adopted by banks.

The significance of this study can be seen through the major attention that was given to the problem of non-performing loans by the banking institutions. Such attention was given to this problem due to the several impacts it has upon commercial banks and which may extend to affect the whole banking system. Due to having such impacts, officials who work in official supervisory bodies - such as Jordanian banks, including the Jordanian central bank - have been exerting much effort to overcome this problem of non-performing loans. These bodies aimed to develop organizational and control measures that are related to non-performing loans. Developing such 
measures aims at protecting the banks and their agents and strengthening these agents trust in the banks they deal with.

The level and activity of the Jordanian banking sector are not less than their counterparts in neighboring countries. In fact, the level and activity of banking sectors in some neighboring countries may exceed their counterparts of the Jordanian banking sector to a point they may considered similar to some global levels. The current study can contribute in investigating the theoretical aspects of one of the most significant problems that has been facing the banking and credit activities. This problem is represented in having non-performing loans and that is something that can be immediately reflected upon the market prices of stocks

\subsection{Statement of the Problem}

The problem of this study is represented in identifying the effects of the spread of non - performing loans in Jordanian commercial banks. Any commercial bank is subjected to facing risks that may affect its financial performance, especially in case it exaggerated in adopting conservative lending policies. For instance, it may face such risks in case it did not provide adequate attention to the quality of the granted loans and to the nature of the guarantees that are being provided by the borrowers. The amounts and effects of non-performing loans usually catch much of the investors' attention.

Jordanian commercial banking sector is not different from any corresponding sector in relation to the possibility of being faced by risks of such type. Thus, the current study aimed at identifying the impact of non - performing loans upon the prices of stocks in Jordanian commercial banks.

In order to achieve the objective of the current study, the researcher shall attempt to provide an answer for the following question:

-What are the impacts of non - performing loans upon stocks' prices in Jordanian commercial banks?

The Study's Model

Independent Variable

Non-Performing Loans

\section{Dependent Variable}

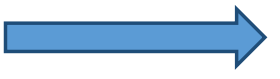

Prices of Stocks

\subsection{The Study's Hypotheses}

The main hypothesis :( Ho) There is no statistically significant impact for non - performing loans upon stocks' prices in Jordanian commercial banks at the significance level of $(\alpha=0.05)$

\section{Review of Theoretical Literature and Previous Studies}

The expression used to refer for " non-performing loans " may differ from one bank to another. For instance, they may be called troubled loans, bad loans, or doubtful loans Before presenting the definitions that have been provided for the concept of non-performing loans, I must state that this problem has negative impacts upon all the relevant parties, such as : the lender, the borrower, and the project involved. Furthermore, the earnings of many governmental agencies will be greatly influenced due to the losses which the relevant projects will incur. Such losses may include: taxes, and social security. In addition, there are many other parties who will be negatively influenced in an indirect manner due to their relationship with the relevant project. Such parties may include: the suppliers, distributers and etc... (Note 1)

There are indicators that have been set to indicate that loans are turning towards becoming non-performing ones. These indicators include the following (Note 2).

1) - Having an increase in the amounts of debts which the borrower owes to various parties.

2) - Having a change in the relationship that the borrower has with the bank. There may be also a lack of cooperation between those two parties which can be noticed through having a delay in reimbursing the concerned debt and having a failure in fulfilling the required obligations.

3) - Having a delay in reimbursing the insurance installments, taxes or any amounts of money that are due to be paid to others.

4) - Having a decrease in the amount of money that is available in the borrower's bank account (current account), which indicates that he suffers from a lack of liquidity. 
5)- Having cash flow problems within the relevant project, so that the borrower wouldn't be able to reimburse the due installments that are related to the relevant loans that have been granted by national and foreign banks to fund the project.

6)- Having negative indictors (such as: losses, decrease in the net and gross profits, deceleration in recovering debts, decrease in the sales volume and the company's incapability to give discounts due to the company's incapability to collect its receivables during the usual period of collecting them.

7)- Deciding to extend the period of collecting the receivable sand having a decline in the agent's cash positions. Indicators also include having a significant increase in the agent's debts which are due to be paid to other parties. Indicators also include having a decrease in the ratio of the inventory turnover and a decrease in the ratio of (liquidity: working capital). Indicators also include having a growing increase in the long - term debts and costs with being associated with a decrease in the profit level. Indicators also include having a huge gap between gross sales and net sales.

8)- Having difficulties in selling the company's products and having a decrease in its marketing capabilities

9)- Having a decrease and a lack of regularity in the productive capacity of the relevant project

Fourth)- Factors that can lead to having non-performing loans)-

Many researchers proposed several reasons that can lead to having non - performing loans. For instance, (Note 3) believes that there is a relationship between having impairment in granting credit facilities in Jordanian commercial banks and each one of the following :

- The credit policy being adopted

- External factors that exist within the environment that surrounds the relevant bank

- The policy being adopted by the central bank in relation to the way of dealing with the other banks

- Factors and reasons related to the officer responsible for granting credit facilities

- Not conducting adequate investigations about the agent's financial situation and managerial abilities.

In addition, (Note 4) believes that the bad political and economic situations are the most significant reasons that can lead to having non - performing loans. As for Sugiura (2002), he believes that non - performing loans result from having an interaction between macroeconomic and microeconomic problems at the level of companies and institutions. As for Al-Khazraji (2004) (Note 5), she believes that non - performing loans may result from technical and administrative reasons, lending policies, working methods, and committing intentional errors. She also believes that such loans may result from reasons related to customers, economic situation and the adopted monetary policies.

\section{No Silver Bullet for Bad Loan problem: (Note 6)}

The study of Sugiura (2002) indicated that the problem of non - performing loans is in constant increase. It also indicated that the current amounts of such loans exceed their corresponding amounts in earlier times. Furthermore, the study of Sugiura (2002) indicated that this problem results from having an interaction between macroeconomic and microeconomic problems at the level of companies and institutions. The most significant reasons that can lead to having such loans include:-the state of recession that the Japanese economy went through, the decline in the prices of real estates, and the major increase in the number of companies and industries. Such significant reasons may also include: failure of some sectors to respond to the process of structural reform that was conducted in the Japanese economy and the incapability of some companies' managements to propose solutions for addressing the problems which their companies are facing.

The study of Sugiura (2002) concluded that due to the spread of the problem of non - performing loans in Japan, the Japanese government gave priority to the way of addressing this problem within its restructuring programs that it has set. The current study concluded that Japanese banks have been exerting major efforts in addressing the problem of having non - performing loans which result from the interaction between problems within the Japanese economy.

The researcher of the current study benefited from the study of Sugiura (2002) in investigating and identifying the intensity of this problem (non - performing loans) in Japan, which economic system is considered one of the strongest ones in the world.

\section{Raspanti \& Szakal (2002): "Creating Value through Credit Risk Mitigation}

The study of Raspanti \& Szakal (2002) dealt with the impacts of having an orientation towards using techniques for reducing the credit risks- upon improving the quality of earnings. Their study also aimed at investigating the impacts of 
having such orientations upon the bank's market value in ordinary and bad situations. Their study also aimed at investigating group of factors. Such factors may include: - (the use of prior preparedness for reducing risks, the use of commercial credit insurance, the bank's strategy in approving or disapproving the risks resulting from the credit portfolio, the technique being adopted for reducing the credit risks). The study of Raspanti \& Szakal (2002) also aimed at investigating the impact of these factors jointly upon the bank's market value.

\section{Altman (2002): Managing Credit Risk: A Challenge for the New Millennium :}

The study of Altman (2002) aimed at identifying the significance of having credit risk management. However, he concluded that the rates of bankruptcy and credit deterioration and impairment are more significant. Furthermore, legislators, supervisors and practitioners who work in the financial market have given more attention to the applications and practices that are appropriate and relevant to such area. Such attention was given due to the: increasing attention given to identifying which techniques are considered appropriate in credit risk management, having constantly changing legislations that are in accordance with Basel agreement, and using credit classification systems, such as: the marks or score systems. Such attention was given due to : the establishments of data bases that are in accordance with the credit deterioration and impairment, conducting recovery processes, and having needs to address the problems related to the guarantees provided for banks to approve granting loans. Such attention was also given due to the development of techniques that aim at reducing credit risks, such as: credit derivatives, credit securitization, and credit insurance products, and the development of techniques that aim at managing credit portfolio.

The study of Altman (2002) concluded that there is an orienting during the new millennium towards adopting newer and more advanced techniques that may participate in reducing the probabilities of facing credit risks. Such techniques may include: using credit derivatives as a tool for hedging, and protection and transferring risks that are associated with credit deterioration and impairment.

\section{Ranson (2003): Credit Risk Management:}

The study of Ranson (2003)aimed to identify the significance of credit risk management. His study also aimed to show that banks' operations are associated and faced with risks like any other type of operations. The bigger these operations are, the more risks will be associated. In addition, the study showed that banks manage various types of risks in the market, such as: the changes in the interest rates, and the movements in the rates of financial instruments. His study also concluded that credit risk is the most significant type of risks which banks may face. The study mentioned some models that are usually used for managing credit risks, such as Moody's model for risk management. His study mentioned names of other models, such as: KMV, ROAC, Zeta, and Z-Score models. His study mentioned the issue of guarantees and that the best type of guarantees are the ones that provide a high liquidity. His study also concluded that providing guarantees doesn't necessarily mean that risks of facing bank ruptcy are decreased. However, providing banks with them is something required for filling gaps after conducting the analytical processes and making the agreements.

The researcher of the current study benefited from the study of Ranson (2003) (Note 7) in identifying and collecting more information about credit risk management. That because the researcher of the current study believes that such information may participate in enriching the theoretical literature that is presented in the current study

\section{Bher \& Lee (2004): "The Effects of Credit Transfer on Bank Monitoring \& Firm Financing"}

The study of Bher \& Lee (2004)aimed at examining the impact of credit risk transfer ( CRT ) - that is associated with the lending portfolio - upon the extent and degree of the control performed by banks. Their study also aimed at identifying whether transferring credit risk may have an impact upon the amounts of funding provided for companies. The model of this study showed how significant diversification is as being one of the rational decisions made in relation to transferring risks. The study of Bher \& Lee (2004)was applied in two banks which possess strict control systems and the highest ratios in the economic system in relation to the amounts of money paid for funding companies and projects. Their study concluded that the strategy of credit risk transfer that has been adopted by some banks could have impacts upon the strategies they have been adopting in conducting their operations.

Their study concluded that credit risk transfer can serve the bank's credit portfolios positively. Such transfer can reduce the bank's desires and motives in having strict control over their borrowers. The statistical analysis that was conducted in their study showed that credit risk transfer can increase the total value of the amounts paid by banks to fund economic entities. Their study concluded that using risk management tools in banks can lead towards reducing the control levels performed by those banks.

Their study recommended paying attention to the significance of merging banks in many regions. It concluded that the positive impacts of merging banks are represented in ability of diversification in reducing various risks. 
The researcher of the current study benefited from the study of Bher \& Lee (2004) in identifying the significance of credit risk transfer in commercial banks.

Michael (2005): Measuring \& Utilizing Corporate Risk Tolerance to Improve Investment Decision Making

The study of Michael (2005) aimed at investigating various strategies that are in relevance to making and disapproving investment decisions in accordance with the risks that are associated with such decisions. His study aimed at examining the companies which play a significant role in making investment decisions and their strategies are oriented towards taking responsibility for the financial risks faced. His study concluded that such strategies have an impact upon the companies' profits and their overall economic status.

The study of Michael (2005) was conducted in one of the business entities that are considered one of the most significant facilities in the United States of America (USA). Its capital is four hundred (400) million US Dollars \$.

The study recommended paying attention to the significance of setting financial strategies for the institutions that are responsible for approving, or disapproving investment decisions in accordance with the risks that are associated with such decisions. Adopting such strategies shall assist companies in managing risks in a way that is better than the companies that make uncertain decisions that are related to their financial risks.

The researcher of the current study benefited from the study of Michael (2005) in identifying and examining various strategies that are related to approving or disapproving investment decisions. The researcher believes that the information of this study may participate in enriching the theoretical literature that is presented in the current study

\section{Kyle\& Fernandez (2005): "Financial Innovation \& risk Management: An Introduction to Credit Derivatives"}

This study aimed at discussing and identifying various types of credit derivatives. It also aimed to identifying their significance in making the market integral. Such credit derivatives can do that through reducing credit impairments and identifying their relationship with the prices of financial products. Furthermore, the major growth which the market of credit derivatives went through has enabled many banks-which works are based on subjecting financial assets to credit risks - to transfer their risks to other parties.

Dealing with credit derivatives can provide many benefits, such as providing financial markets with liquidity during crises and keeping the retail credit portfolios in possession of liquidity during various stressful situations. Dealing with such derivatives can also provide a method for splitting credit risks from other types of risks that may arise from credit tools, such as: market risks, or operational risks.

The study concluded that banks seek towards searching for hedging tools to face and reduce the risks associated with credit portfolio. The study also concluded that the size and liquidity of the credit derivatives market have increased in response to the attempts made by a number of participants who seek to apply hedging. The study also concluded that credit derivatives facilitate having more specific and efficient for credit risks pricing.

The researcher of the current study benefited from the study of Kyle \& Fernandez (2005) in identifying the various types of credit derivatives and their significance in making the market integral through reducing credit impairments.

\section{Kristiansen (2006): "Strategic Bank Monitoring \& Firms Debt Structure"}

The study of Kristiansen (2006) aimed at identifying the impact of reducing the control levels upon credit through examining the borrowers' data, credit agreements and contracts, pledges that the borrowers have taken and the terms that are imposed upon them. Such agreements, contracts, pledges and terms lead to having a good quality of credit portfolio. That is because such agreements, contracts, pledges and terms affect the borrowers' decisions in relation to which debt structure or amounts of funding are considered appropriate for them to adopt. That leads to increasing the efficiency of banks' self-control and protecting banks from any unexpected credit changes.

The researcher of the current study benefited from the study of Kristiansen (2006)through identifying one of the most significant factors that can lead to having non - performing loans, which is represented in the level of control imposed upon credit.

\section{Salima et al. (2012): Impact of Late Payment (LP) on Firms' Profitability: Empirical Evidence from Malaysia}

The study of Salima et al. (2012) aimed at examining whether agent's late payment may affect companies' profits or not. The researcher chose a cross-sectional sample that consisted of two hundred and eighty-seven ( 287 ) Malaysian public companies that are listed in the stock exchange market for the fiscal year of 2007. The study's subject is considered very significant because commercial credit is considered significant in relation to the short - term funding in Asia. However, commercial credit has not been much adopted in Malaysia, because there aren't much relevant 
published data. It is also because companies refuse to disclose information that are related to their commercial credit practices.

Sixty percent ( $60 \%$ ) of their study's sample showed that agents' late payments have a negative influence upon companies' profits. Their study also concluded that companies that set short - term credit conditions and have "days sales outstanding (DSO)" showed a performance that is better than the ones that set long - term credit conditions and require a long period of time to have "days sales outstanding (DSO)". The study of Salima et al. (2012) recommended conducting studies to know whether agents' late payment have negative impacts upon increasing the companies' risks and thus, that would affect their stocks' market prices.

The researcher of the current study benefited from the study of Salima et al. (2012) in identifying the negative impact of agents' late payments upon companies' profits.

\section{The Study's Methodology}

The current study has adopted a descriptive analytical approach because it aimed at identify whether there is a statistically significant impact for non - performing loans upon the prices of stocks or not in Jordanian commercial banks at the significance level of $(a=0.05)$.

3.1 The Study's limits: $2005-2015$

\subsection{Methods of Collecting Data}

3.2.1 Secondary sources:-Such sources include: books, references, periodicals, articles and previous studies. These sources are considered as the most significant sources for collecting secondary data in order to enrich the theoretical part of the current study.

3.2.2 Primary sources:-Such sources include the financial reports of the banks that are listed in the study's sample during the period ( $2005-2015$ ).

\subsection{Testing the Study's Hypotheses}

(Ho) :There is no statistically significant impact for non - performing loans upon the prices of stocks in Jordanian commercial banks at the significance level of $(a=0.05)$.

The researcher conducted a simple regression analysis for testing the aforementioned hypothesis. Thus, the researcher of the current study has concluded the following : 


\subsection{Model Summary}

\begin{tabular}{|c|c|c|c|c|}
\hline Model & $\mathrm{R}$ & R Square & $\begin{array}{l}\text { Adjusted } \\
\text { Square }\end{array}$ & $\begin{array}{l}\mathrm{R} \text { Std. Error of the } \\
\text { Estimate }\end{array}$ \\
\hline 1 & $.420^{\mathrm{a}}$ & .176 & .170 & 3.54235 \\
\hline
\end{tabular}

a. Predictors: (Constant), loans

\begin{tabular}{lllllll}
\hline ANOVA $^{\mathbf{b}}$ & & & & \\
\hline Model & & Sum of Squares & Df & Mean Square & F & Sig. \\
\hline 1 & Regression & 341.512 & 1 & 341.512 & 27.216 & $.000^{\mathrm{a}}$ \\
\cline { 2 - 7 } & Residual & 1593.625 & 127 & 12.548 & & \\
\cline { 2 - 6 } & Total & 1935.138 & 128 & & & \\
\hline
\end{tabular}

a. Predictors: (Constant), loans

b. Dependent Variable: price

\begin{tabular}{|c|c|c|c|c|c|c|}
\hline \multicolumn{7}{|c|}{ Coefficients } \\
\hline \multirow[b]{2}{*}{ Model } & & \multicolumn{2}{|c|}{ Unstandardized Coefficients } & \multirow{2}{*}{$\begin{array}{l}\text { Standardized } \\
\text { Coefficients } \\
\text { Beta }\end{array}$} & \multirow[b]{2}{*}{$\mathrm{t}$} & \multirow[b]{2}{*}{ Sig. } \\
\hline & & B & Std. Error & & & \\
\hline \multirow[t]{2}{*}{1} & (Constant) & 2.745 & .368 & & 7.461 & .000 \\
\hline & loans & 8.384E-9 & .000 & .420 & 5.217 & .000 \\
\hline
\end{tabular}

a. Dependent Variable: price

We can notice that the calculated $\mathrm{F}$ value $=27.216$ is considered statistically significant and thus, we reject the aforementioned null hypothesis (Ho). In other words, there is a statistically significant impact for then on - performing loans upon the prices of stocks in Jordanian commercial banks at the significance level of ( $a=0.05$ ).

The value of the correlation coefficient $r$ is 0.42 which reflects a moderate relationship of correlation. Furthermore, the independent variable can explain and interpret $17.6 \%$ of the change that has occurred upon the dependent variable because the value of $r^{2}$ is 0.176 .

\section{The regression equation is as follows:}

(Non-performing loans) $8.384 \mathrm{E}-9+2.745=$ the stock price

\section{Conclusion}

The current study aimed at identifying whether there is a statistically significant impact for the non - performing loans upon the prices of stocks or not in Jordanian commercial banks at the significance level of ( $a=0.05)$. This study was concerned with investigating the Jordanian commercial banking sector during the period of (2005-2015). The current study has given great attention to this sector because it is considered as the most vital sector in the Jordanian economic system. However, it was concluded that there is a statistically significant impact for the non - performing loans upon the prices of stocks in Jordanian commercial banks at the significance level of $(a=0.05)$. Thus, that indicates that it is necessary to address the problem of having non - performing loans, because it is a problem that deserves to get much attention by the ones investing in the stock exchange market of Amman. The problem of non - performing loans can be addressed through increasing the transparency level of the financial information provided about the banks that are listed in the stock exchange market of Amman. This problem can be also addressed through providing more accurate credit information about agents before granting them loans. In addition, it is necessary to keep up with the most advanced technological methods that are used in granting credit facilities. This study also shows that there is a need to review the credit policies that have been already set in a way that guarantees having more accuracy in the process of granting loans. This study also shows that there is need for training workers in applying the credit policy that is being adopted. Such training should raise the practical efficiency levels of those employees. The study also showed that banks' control should be stricter and they should set more dissuasive penalties in relation to granting facilities without having adequate guarantees. 


\section{References}

Abed Al-Gh'ani, Dadan. (2006). Analyzing the financial performance and prices of economic institution. The Researcher Journal, 4, 41 - 48.

Abu Khazaneh, Ehab Mohammad Ahmad. (2007). Credit management: A proposed model for measuring risks of bank credit in the aim of enhancing the accounting disclosure in commercial banks, credit management, Bank of Alexandria.

Abu Obaida, Jamal. (2003). Non - performing loans in Jordanian commercial banks: Reasons, impact and possible solutions: Unpublished PhD dissertation, Amman Arab University for Graduate Studies, Amman, Jordan.

Al-Bur'asi, Najib. (2005). Addressing the phenomenon of non - performing loans in Libyan public commercial banks : Reasons, impact and possible solutions, Analytical study: Unpublished $\mathrm{PhD}$ dissertation, Arab Academy for Banking and Financial Sciences, Jordan

Al-Dagh'im et al. (2006). Credit analysis and a course in rationalizing the operations of bank lending: Empirical study Applied in a Syrian industrial bank. Journal of October University for Scientific Research and Studies, 28(3).

Al-Khalayleh, Mahmoud Abed Al-Halim. (2001). The relationship between accounting performance indicators and market performance indicators (stock returns). Journal of Studies in Managerial Sciences, The University of Jordan, 28(1).

Al-Khazraji, Sameera Hussain. (2004). Problem of doubtful loans and unrecovered loans in Iraqi Banks, A research submitted for the Directorate General of statistics and statistics, The Iraqi Central Bank, Baghdad..

Al-Sayah, Abed Alsatar and Al-Ameri, Su'd. (2007). Financial management : theoretical framework and empirical cases, Dar Wa'el Publishing House, Amman, Jordan

Altman, E.I. (2002). Managing Credit Risk, A Challenging for the New Millennium. Economics Notes, 31(2), 201-214. https://doi.org/10.1111/1468-0300.00084

Awad, Muhsen Fayez. (2006). Using an analytical approach to measure the performance of the Jordanian banking sector, Unpublished PhD dissertation, Arab Academy for Banking and Financial Sciences, Jordan.

Bher, P. \& Lee. S. (2004). "The Effects of Credit Transfer on Bank Monitoring \& Firm Financing", Goethe University, Frankfurt, D82, G21, G32.

Daw, Amer Khalifa. (2012). Analyzing the impact of bank centralization and market share upon the performance of commercial banks, Unpublished PhD Dissertation, Amman Arab University, Amman - Jordan

Geany. H. (1999). Assessing the Conditions of Japanese Banks: How informative Are Accounting Earnings? Economic perspectives Federal Reserve Bank of Chicago, 15, 12-34.

Haddad, Wasim. (2005). Non - performing loans in Jordanian commercial banks, Unpublished MA thesis, Yarmouk University, Jordan.

http://www.awraq.com

Kristiansen, G. E. (2006). Strategic Bank Monitoring \& firms' Debt Structure. Department of Economics, Norwegian School of Economics \& Business Administration, Norway, D82, G32, G21, L14.

Kyle, B. \& Fernandez, F. (2005). Financial Innovation \& Risk Management, An Introduction to Credit Derivatives", Journal of Applied Finance, 15(1), 52 - 63.

Meftah, Saleh and Ma'arfi, Farida. (2007). Analyzing, measuring, managing and reducing credit risks, A presentation presented in the seventh $\left(7^{\text {th }}\right)$ Annual International Scientific Conference, Risk management and knowledge economy - Faculty of Economic and Managerial Sciences, Al-Zaytooneh University, Jordan, $16^{\text {th }}-18^{\text {th }}$ April 2007

Michael, W. (2005). Measuring \& Utilizing Corporate Risk Tolerance to improve investment Decision Making. Engineering Economist, 50(4), 361-376. https://doi.org/10.1080/00137910500348434

Othman, Mohammad. (2008). The impact of the techniques used to reduce the credit risks upon the banks' market value - An empirical study applied in the Jordanian commercial banking sector through using the equation of Tobin's Q, Unpublished PhD dissertation, Arab Academy for Banking and Financial Sciences, Jordan.

Ranson, Brian J. (2003). Credit Risk Management, Austin. TEXAS.

Raspanti, T. M \& Szakal, E. (2002). Creating Value through Credit Risk Mitigation. Business Credit, 104(3), 1-4. 
Salima Y., Devi S., Chee T. (2012). Impact of late payment on Firms' profitability: Empirical evidence from Malaysia, Pacific-Basin Finance Journal, 20, 777-792. https://doi.org/10.1016/j.pacfin.2012.03.004

Shabib, Duraid Kamel. (2009). Introduction to Contemporary financial management, Al-Masira Distribution and Publishing House, Amman, Jordan.

Shahin Ali \& Sabah, Baheye. (2011). The impact of risk management upon the degree of integrity of the Palestinian banking system. Journal of Al-Aqsa University (The series of Human sciences), 15(1), 1 - 29.

Sugiura, Tetsuro. (2002). NO Silver Bullet for Bad Loan problem, Fuji Research Institute Corporation, Tokyo.

Zaydeh, Dua'a. (2006). Impaired credit facilities and the Palestinian banking system: Empirical study Applied in national banks located in Ghaza, Unpublished MA thesis, The Islamic University of Ghaza.

\section{Notes}

Note 1. Al-Khazraji, Sameera Hussain. (2004). Problem of doubtful loans and unrecovered loans in Iraqi Banks, A research submitted for the Directorate General of statistics and statistics, The Iraqi Central Bank, Baghdad

Note 2. Abu Obaida, Jamal. (2003). Non - performing loans in Jordanian commercial banks: Reasons, impact and possible solutions: Unpublished $\mathrm{PhD}$ dissertation, Amman Arab University for Graduate Studies, Amman, Jordan

Note 3. Haddad, Wasim. (2005). Non - performing loans in Jordanian commercial banks, Unpublished MA thesis, Yarmouk University, Jordan

Note 4. Sugiura, Tetsuro. (2002). NO Silver Bullet for Bad Loan problem, Fuji Research Institute Corporation, Tokyo.

Note 5. Al-Khazraji, Sameera Hussain (2004). Problem of doubtful loans and unrecovered loans in Iraqi Banks, A research submitted for the Directorate General of statistics and statistics, The Iraqi Central Bank, Baghdad

Note 6. Sugiura, Tetsuro. (2002). NO Silver Bullet for Bad Loan problem, Fuji Research Institute Corporation, Tokyo. Note 7. Ranson, Brian J. (2003). Credit Risk Management, Austin. TEXAS. 